\title{
Correction to: Recommendations for the Development of Cell-Based Anti-Viral Vector Neutralizing Antibody Assays
}

\author{
Boris Gorovits, ${ }^{1,8}$ Michele Fiscella, ${ }^{2}$ Mike Havert, ${ }^{3}$ Eugen Koren, ${ }^{4}$ Brian Long, \\ Mark Milton, ${ }^{6}$ and Shobha Purushothama ${ }^{7}$
}

\section{Correction to: AAPS J https://doi.org/10.1208/s12248-019-0403-1}

The first author's name was published incorrectly as "Gorovits Boris". The correct name is "Boris Gorovits".

There are also several errors in the co-author affiliations. The correct affiliations are below.

Boris Gorovits ${ }^{1}$, Michele Fiscella ${ }^{2}$, Mike Havert ${ }^{3}$, Eugen Koren $^{4}$, Brian Long ${ }^{5}$, Mark Milton ${ }^{6}$, Shobha Purushothama ${ }^{7}$

${ }^{1}$ Pfizer Inc. MA, USA

${ }^{2}$ REGENXBIO Inc., MD, USA

${ }^{3}$ bluebird bio, MA, USA

${ }^{4}$ Precision for Medicine, Inc. CA, USA

${ }^{5}$ BioMarin Pharmaceutical Inc, CA, USA

${ }^{6}$ Novartis Institutes for BioMedical Research, Inc., MA, USA

${ }^{7}$ Alzheimer's Drug Discovery Foundation, USA

In addition, incorrect spacing occurred on the PDF between words on page 23, in the Acknowledgements section.

The online version of the original article can be found at https:// doi.org/10.1208/s12248-019-0403-1

\footnotetext{
${ }^{1}$ Pfizer Inc., Andover, MA, USA.

${ }^{2}$ REGENXBIO Inc., Rockville, MD, USA.

${ }^{3}$ bluebird bio, Cambridge, MA, USA.

${ }^{4}$ Precision for Medicine, Inc., Costa Mesa, CA, USA.

${ }^{5}$ BioMarin Pharmaceutical Inc, Novato, CA, USA.

${ }^{6}$ Novartis Institutes for BioMedical Research, Inc., Cambridge, MA, USA.

${ }^{7}$ Alzheimer's Drug Discovery Foundation, New York, NY, USA.

${ }^{8}$ To whom correspondence should be addressed. (e-mail: Boris.Gorovits@pfizer.com)
}

\section{ACKNOWLEDGMENTS}

Manuscript authors worked as part of the American Association of Pharmaceutical Scientists community and are sincerely grateful to the entire AAPS organization for the support and opportunities provided.

\section{Glossary AAV adeno-associated virus}

AAV - binding (total) antibodies (Tab) immunoglobulins able to specifically bind to AAV capsid protein epitopes. These antibodies may be neutralizing or non-neutralizing

AAV neutralizing antibodies (NAb) - immunoglobulins able to specifically bind to AAV capsid protein epitopes and inhibit one or more critical steps involved in AAV infectivity and cell transduction

Companion diagnostic (CDx) - an in vitro test method which provides information that is essential for the safe and effective use of a corresponding drug or biologic product

Gene therapy (GTx) - a technique that uses genes, or genetic modification, to treat or prevent disease

Transgene - a gene that is transferred due to GTx treatment Transgene expression of mRNA or protein

Viral vector - viral based tools used to deliver genetical material to cells

The original article has been corrected. 